Mawa'izh

Jurnal Dakwah dan Pengembangan Sosial Kemanusiaan

Vol. 9, no. 2 (2018), pp. 154-177.

DOI: https://doi.org/10.32923/maw.v9i2.783

\title{
Dialog dan Kerjasama Antar Umat Beragama dalam Perspektif Nurcholish Madjid
}

\section{Zaprulkhan}

IAIN Syaikh Abdurrahman Siddik Bangka Belitung, Indonesia

zaprulkhan_zahra@yahoo.co.id

\begin{abstract}
When leaving the end of the second millennium and entering the beginning of the third millennium, humankind is faced with the phenomenon of conflict in the name of religion, both on a regional and global level. In modern history, there are so many conflicts that occur in the name of beliefs in different parts of the world. In the context of Indonesia, the both of impacts of various conflicts and conflicts between various beliefs are rising to the surface ahead of the beginning of the third millennium to the present day. All this requires a dialogue and open cooperation between religious communities. In the context of Indonesia, in order to contribute maximally to the good, and the progress of the nation and state, all religious people must be willing to engage in dialogue and cooperation in the social, cultural, economic, political, human quality of Indonesia and others. Therefore, we will explore the discourse of dialogue and cooperation among religious people in the perspective of Nurcholish Madjid.
\end{abstract}

Keywords: Dialogue, Cooperation, Religious People, Nurcholish Madjid.

\begin{abstract}
Abstrak: Ketika meninggali penghujung milenium kedua dan memasuki awal milenium ketiga, umat manusia disuguhkan dengan fenomena konflik atas nama agama, baik di level regional maupun global. Dalam sejarah modern, puspa ragam konflik-konflik yang terjadi atas nama kepercayaan di berbagai belahan dunia. Pada konteks Indonesia, dampak dari berbagai konflik maupun terjadinya konflik antar beragam keyakinan menyeruak ke permukaan pada awal milenium ketiga hingga hari ini. Segala permasalahan ini menuntut suatu dialog dan kerjasama yang saling terbuka antar kelompok-kelompok beragama. Pada konteks Indonesia, agar dapat berkontribusi dengan maksimal menuju suatu kemaslahatan, dan kemajuan bangsa dan Negara, semua umat beragama harus terlibat tulus dalam suatu dialog dan kerjasama di berbagai bidang seperti sosial, ekonomi, politik, kualitas manusia Indonesia, dan sebagainya. Oleh sebab itu, penulis akan mengeksplorasi wacana dialog dan kerjasama antar umat beragama dalam terang perspektif Nurcholish Madjid.
\end{abstract}

Kata kunci: Dialog, Kerjasama, Umat Beragama, Nurcholish Madjid.

Received: 05-11-2018; accepted: 30-11-2018; published: 20-12-2018

Citation: Zaprulkhan, 'Dialog dan Kerjasama Antar Umat Beragama dalam Perspektif Nurcholish Madjid', Mawai'zh, vol. 9, no. 2 (2018), pp. 154-177. 


\section{A. Pendahuluan}

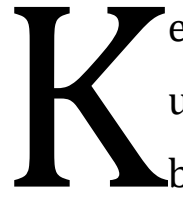

etika meninggalkan akhir milenium kedua dan memasuki awal milenium ketiga, umat manusia justru disuguhkan dengan fenomena konflik atas nama agama, baik dalam tataran regional maupun global. Dalam sejarah modern, terdapat begitu banyak konflik yang terjadi atas nama keyakinan diberbagai belahan dunia. Fenomena konflik atas nama agama juga bisa kita lihat di berbagai belahan dunia lainnya: Mesir, Jerman, Italia, Prancis, Inggris, Peru, Jepang, dan Palestina, ${ }^{1}$ Riyadh, Chechnya, dan Casablanca. ${ }^{2}$ Bahkan konflik berbau agama juga terjadi secara masif di beberapa negara di kawasan Asia Tenggara, antara lain Thailand, Filipina, Malaysia, dan termasuk juga Indonesia. ${ }^{3}$ Nada kebencian inipun diikuti oleh pengkhutbah semacam Jerry Falwell, Pat Robertson, Rod Parsley, dan John Hagge untuk menyebut sejumlah kecil eksemplar. ${ }^{4}$

Dalam konteks Indonesia, beragam benturan dan berbagai fenomena konflik antar berbagai keyakinan menyeruak ke permukaan menjelang awal milenium ketiga hingga hari ini. Sasaran teror juga semakin meluas ke arah gedung-gedung, bangunan, dan berbagai fasilitas publik yang dianggap representasi negara asing "musuh-musuh Islam". 5 Terakhir adalah munculnya fenomena gerakan radikalisme yang berjubah keagamaan dengan sebutan Negara Islam Irak dan Suriah (Islamic State of Iraq and Syria) atau ISIS yang dengan lantang mengikrarkan hendak mendirikan negara Islam, daulah islamiyah atau khilafah islamiyah. ${ }^{6}$

Dalam konteks Indonesia, di penghujung abad 20, Nurcholish Madjid (Cak Nur) pun sudah memiliki keprihatinan atas berbagai kerusuhan baik yang bernuansa agama maupun etnik seperti di Situbondo, Tasikmalaya, Rengas-Dengklok, Kalimantan Barat, dan lain-lain. ${ }^{7}$ Cak Nur melihat ada sesuatu yang bersifat kontradiktif bahkan anomali dalam kehidupan antar umat beragama di Indonesia. Kita bangsa Indonesia yang selama ini dikenal sebagai bangsa yang toleran dan rukun, tapi justru terjadi kerusuhan keagamaan, baik intern satu agama maupun antara agama-agama yang berbeda. Karena

\footnotetext{
${ }^{1}$ Alwi Shihab, Membedah Islam Di Barat (Jakarta: Gramedia, 2011), p. 5.

${ }^{2}$ Zuhairi Misrawi, Pandangan Muslim Moderat (Jakarta: Kompas, 2010), p. 109.

3 Zaki Mubarak, Genealogi Islam Radikal di Indonesia (Jakarta: LP3ES, 2008), p. 2.

${ }^{4}$ John L. Esposito, Masa Depan Islam (Bandung: Mizan, 2010), pp. 249-50.

${ }^{5}$ Zaki Mubarak, Genealogi Islam Radikal di Indonesia, p. 3-4.

${ }^{6}$ Pembahasan mengenai kontroversi khilafah secara luas, bisa dibaca dalam Komaruddin Hidayat (ed.), Kontroversi Khilafah, Islam, Negara, dan Pancasila (Bandung: Mizan, 2014).

${ }^{7}$ Komaruddin Hidayat dan Ahmad Gaus AF (ed.), Passing Over (Jakarta: Gramedia Pustaka Utama, 2001), pp. xxvii-xxviii.
} 
Mawa'izh

Jurnal Dakwah dan Pengembangan Sosial Kemanusiaan

Vol. 9, no. 2 (2018), pp. 154-177.

DOI: https://doi.org/10.32923/maw.v9i2.783

itu, menurut Cak Nur persoalan kerukunan antar umat beragama perlu ditinjau kembali dan dicarikan solusinya.

Begitu pula, Cak Nur sudah mengantisipasi pengaruh globalisasi yang menghilangkan batas-batas antara berbagai bangsa, komunitas dan agama. Seperti komunitas agama akan berjumpa dengan berbagai komunitas lainnya sehingga setiap umat beragama harus mempunyai perspektif yang tepat tentang agama mereka masingmasing dan kesadaran positif mengenai adanya perbedaan di antara mereka. Semua ini meniscayakan adanya dialog secara terbuka antar umat beragama. Dalam konteks Indonesia, agar dapat memberikan kontribusi secara maksimal bagi kebaikan, dan kemajuan bangsa dan negara, semua umat beragama harus bersedia melakukan dialog dan kerjasama dalam tataran sosial, kultural, ekonomi, politik, kualitas manusia Indonesia dan lain-lain. Karena itu, kita akan mengeksplorasi wacana dialog dan kerjasama antar umat beragama dalam perspektif Cak Nur.

\section{B. Konstruksi Dialogis Antar Umat Beragama}

Dalam perspektif Cak Nur, untuk membangun hubungan dialogis antar umat beragama salah satu piranti yang harus dilakukan adalah mencari titik temu, landasan bersama atau dalam bahasa Al-Qur'an disebut dengan kalimah sawa. Menurut Cak Nur, istilah Arab kalimah sawa berarti kalimat, ide, atau prinsip yang sama, yakni ajaran yang menjadi common platform antara berbagai kelompok manusia. Dalam kitab suci, Allah memerintahkan Nabi Muhammad, rasul-Nya, agar mengajak komunitas keagamaan yang lain, khususnya para penganut kitab suci (Ahlal-Kitab) untuk bersatu dalam titik pertemuan itu:

"Katakan (olehmu, Muhammad), "Wahai para penganut kitab suci, marilah semuanya menuju ajaran bersama antara kami dan kamu sekalian, yaitu bahwa kita tidak menyembah kecuali Tuhan dan tidak memperserikatkanNya kepada sesuatu apapun, dan kita tidak mengangkat sesama kita sebagai tuhan-tuhan selain Tuhan Yang Maha Esa (Allah)". Tetapi jika mereka (para penganut kitab suci) itu menolak, katakanlah olehmu sekalian (engkau dan para pengikutmu), "Jadilah kamu sekalian (wahai para penganut kitab suci) sebagai saksi bahwa kami adalah orang-orang yang pasrah kepada-Nya (muslimun)". (QS. 3: 64) ${ }^{8}$

${ }^{8}$ Budhy Munawar Rachman (peny.), Ensiklopedi Nurcholish Madjid Vol. 2 (Jakarta: Paramadian, 2006), p. 1267. 
Ajakan pada semua komunitas agama yang berbeda untuk mencari titik pertemuan bersama inilah sebagai pijakan dasar dalam membangun dialog antar umat beragama. Dalam firman Tuhan tersebut, menurut Cak Nur ada beberapa prinsip yang perlu kita perhatikan. Pertama, adanya perintah mencari titik temu antara para penganut berbagai agama yang berkitab suci; kedua, titik temu itu ialah tawhid atau paham Ketuhanan Yang Maha Esa (monoteisme); ketiga, tawhid itu menuntut konsekuensi tidak adanya pemitosan sesama manusia atau sesama makhluk; keempat, jika usaha menemukan titik temu itu gagal atau ditolak, maka masing-masing harus diberi hak untuk secara bebas mempertahankan sistem keimanan yang dianutnya. ${ }^{9}$

Pada butir prinsip yang keempat, ketika titik temu dalam dialog itu tidak ditemukan juga, maka setiap umat beragama diberi kebebasan mengikuti sistem keyakinannya masing-masing. Mengapa demikian? Menurut Cak Nur, karena pluralitas umat manusia dalam berbagai aspeknya, termasuk keyakinan mereka, telah menjadi kehendak abadi Tuhan; Sehingga tidak ada yang dapat memaksa umat manusia menjadi monolistik dan sepakat dalam satu hal untuk semua dimensi kehidupan mereka, apalagi dalam hal keimanan mereka.

Berkenaan dengan hal ini, Cak Nur menurunkan beberapa ayat Al-Qur'an yang relevan:

"Dan seandainya Tuhanmu menghendaki, maka pastilah Dia jadikan manusia umat yang tunggal. Namun mereka akan tetap berselisih, kecuali yang Tuhamu merahmatinya. Lantaran itulah Dia ciptakan mereka itu, dan telah sempurnalah kalimat (keputusan) Tuhanmu: "Pastilah Aku penuhi Jahannam dengan isi dari jin dan manusia".

Jadi ditegaskan bahwa (1) Tuhan tidak menghendaki manusia dalam keadaan yang tunggal atau monolitik; (2) Manusia akan tetap senantiasa berselisih; (3) Yang tidak berselisih ialah mereka yang mendapat rahmat Tuhan; (4) Untuk design itulah Tuhan menciptakan manusia; (5) Kalimat keputusan atau ketetapan Tuhan ini telah sempurna, tidak akan berubah; (6) Kebahagiaan dan kesengsaraan abadi bersangkutan dengan masalah perbedaan antara sesama manusia dan perselisihan mereka.

Itulah Hukum Ketetapan Allah (sunnatullah) bagi manusia. Hukum Ketetapan Allah itu tidak akan berubah ataupun beralih selama-lamanya, jadi bersifat abadi atau perennial dan immutable. Karena sifatnya yang tetap abadi itu maka sunatullah dapat 
dipedomani dan dijadikan landasan tindakan kemanusiaan dalam menjalani hidup dan menghadapi beragam persoalan-persoalan hidup"10

"Dan jika Tuhanmu menghendaki, niscaya semua manusia yang ada di bumi beriman seluruhnya. Hendak kau paksa jugakah orang supaya beriman?" (QS. Yunus 10: 99). ${ }^{11}$

Dengan bersandar pada tafsir Abdullah Yusuf Ali, Cak Nur menguraikan bahwa sekiranya Allah menghendaki atau berkenan, kemauan bebas terbatas yang selama ini sudah diberikan kepada manusia tidak diberikan, maka dengan kemahakuasaan-Nya Ia akan membuat semua umat manusia sama: semua beriman. Tapi iman yang demikian tidak akan memantulkan pahala apa-apa kepada mereka. Dalam kenyataan dunia ini, manusia telah dianugerahi bermacam-macam kemampuan dan kecerdasan, sehingga dengan demikian mereka akan berjuang dan berusaha keras, dan menempatkan dirinya sesuai dengan kehendak Allah.

Di sini iman akan menjadi suatu prestasi moral, dan iman agar tidak menjadi suatu dosa. Sebagai pegangan pelengkap, orang beriman tidak boleh marah jika berhadapan dengan orang yang tak beriman. Dan yang paling penting dari semua itu, ia harus bisa menahan diri dari godaan melakukan kekerasan. Misalnya, memaksakan iman kepada orang lain dengan paksaan fisik, atau dengan paksaan lain, seperti tekanan sosial, membujuk dengan harta atau kedudukan, dan lain-lain. Iman yang dipaksakan bukanlah iman. Mereka harus berusaha dengan jalan rohani, dan biarlah Tuhan yang menentukan sesuai dengan kehendak-Nya. ${ }^{12}$

Berdasarkan pada pijakan-pijakan normatif yang disuguhkan oleh Cak Nur, di sini pun kita dapat memperluas wacana dialog antar umat beragama yang digulirkan Cak Nur dalam berbagai aspek kehidupan. Menurut Amin Abdullah, pencarian titik temu lewat perjumpaan dan dialog yang konstruktif berkesinambungan adalah merupakan tugas kemanusiaan yang perennial, yang abadi, tanpa henti-hentinya. Pencarian titik temu antar umat beragama dapat dimungkinkan lewat berbagai cara, salah satunya adalah lewat pintu masuk etika, lantaran lewat pintu gerbang etika manusia beragama secara universal menemui tantangan-tantagan kemanusiaan yang sama. Lewat pintu etika ini-untuk tidak mengatakan lewat pintu teologis-manusia beragama merasa mempunyai puncakpuncak keprihatinan yang sama.

${ }^{10}$ Nurcholish Madjid, Masyarakat Religius (Jakarta: Paramadina, 2000), pp. 25-6.

${ }^{11}$ Hidayat, Passing Over, p. 182.

12 Ibid., pp. 182-3. 
Untuk era sekarang, tantangan scientisme dengan berbagai implikasinya, tantangan lingkungan hidup, menjunjung tinggi harkat kemanusiaan (human dignity), menghormati hak asasi manusia adalah merupakan agenda bersama umat manusia tanpa pandang "bulu" keagamaannya. Lewat pintu etika ini, seluruh penganut agama-agama dapat tersentuh "regionalitas"nya, untuk tidak hanya menonjolkan "having a religion"nya. Lewat pintu etika, dimensi spiritualitas keberagamaan lebih terasa promising and challenging dan bukannya hanya terfokus pada formalitas lahiriyah kelembagaan agama. 13

Dalam konteks ini, kita bisa meminjam analisis J.B. Banawiratma mengenai dialog antar umat beragama, baik pada tataran refleksi etis maupun tataran aksi riil dalam kehidupan nyata. Dialog antar umat beragama adalah pembicaraan yang di dalamnya dua pihak atau lebih berusaha mengemukakan pandangan mereka secara akurat dan mendengarkan dengan penuh hormat lawan bicaranya. Selama paro kedua abad kedua puluh, acara-acara dialog yang terorganisasi bertambah banyak di tingkat lokal, regional, dan internasional. Pertemuan itu sangat bervariasi dalam hal organisasi, fokus, dan tempat, begitu pula komposisi pesertanya.

Ada beberapa motif yang mendorong gerakan dialog ini. Antara lain, keinginan untuk memupuk pemahaman, merangsang komunikasi, memperbaiki stereotip, menangani permasalahan tertentu yang menyangkut kepentingan bersama, menyingkap persamaan dan perbedaan, serta mempermudah sarana kesaksian dan kerja sama. ${ }^{14}$

Dengan mengacu pada Banawiratma, dialog dipahami dalam makna seluasluasnya agar dapat menampung sebanyak mungkin potensi yang ada untuk dikembangkan. ${ }^{15}$ Ketika orang berbeda iman saling bertemu dan menyapa, di situ terjadi dialog antarumat beriman. Apapun isi yang dikomunikasikan, dialog terjadi. Dialog antarumat beragama pertama-tama dilihat dari bawah, dari perjumpaan dalam kenyataan hidup sehari-hari. Dengan pengertian itu, dialog yang secara eksplisit mengungkapkan isi iman dan agama tidaklah dikesampingkan, melainkan juga dikembangkan sesuai dengan fungsinya secara kontekstual.

13 M. Amin Abdullah, Studi Agama (Yogyakarta: Pustaka Pelajar, 1996), pp. 72-3.

14 John L. Esposito (ed.), Ensiklopedi Oxford Dunia Islam Modern Jilid 4, trans. by Eva Y.N, et al. (Bandung: Mizan, 2001), pp. 128-9.

15 Konsep dialog ini sebagian besar diambil dari J. B. Banawiratma, et al., Dialog Antarumat Beragama, (Bandung: Mizan, 2010), pp. 7-14. 
Dialog yang berkembang dari bawah dapat digambarkan dengan tujuh dataran yang berhubungan satu sama lain. Dataran-dataran dialog itu dapat dilihat sebagai langkah-langkah yang fleksibel dan dapat melompat. Dataran-dataran dialog itu juga dapat disebut momen-momen dialog sebab usaha dan tindakan berdialog umumnya tidak berangkat dari titik nol, ia juga dapat dilaksanakan pada dataran mana saja yang mungkin pada lingkungan dan waktu tertentu. Dataran-dataran atau momen-momen itu dapat digambarkan sebagai berikut:

1) Dialog kehidupan

2) Analisis sosial dan refleksi etis kontekstual

3) Studi tradisi-tradisi agama

4) Dialog antar umat beragama: berbagi iman dalam level pengalaman

5) Dialog antar umat beragama: berteologi lintas agama

6) Dialog aksi

7) Dialog intraagama

Dataran-dataran itu dapat juga digambarkan sebagai lingkaran praksis, artinya sebagai gerak yang berangkat dari praksis yang sudah ada menuju praksis yang dikembangkan lebih lanjut. Lingkaran praksis itu tidak tertutup dan tidak berhenti, melainkan dapat menjadi proses berkelanjutan, sehingga dapat juga disebut sebagai spiral praksis.

Proses penafsiran kenyataan hidup melalui analisis sosial dan refleksi etis dapat juga diperdalam dengan penafsiran teks agama, dan dengan demikian lingkaran praksis ini juga merupakan lingkaran hermeneutik. Lingkaran praksis atau lingkaran hermeneutik tidak mulai dari titik nol, ketujuh dataran itu bukanlah langkah-langkah yang harus dilalui semuanya, ia dapat dimulai dari mana saja dan dapat dilompati, misalnya dari dialog kehidupan sehari-hari (1) melalui analisis dan pertimbangan etis (2) melompat ke aksi (6). Dapat juga misalnya dari berbagi iman dalam level pengalaman (4) melompat ke aksi (6). Begitulah tujuh dataran ini merupakan medan dialog yang sangat fleksibel. Berikut ini keterangan singkat mengenai dataran-dataran tersebut.

Dialog pada dataran pertama disebut dialog kehidupan. ${ }^{16}$ Dialog itu terjadi dalam komunitas kecil yang menghadapi hidup keseharian bersama. Anggota-anggota komunitas laki-laki dan perempuan yang berbeda-beda agama saling mengenal satu sama

16 Untuk lebih luasnya mengenai dialog kehidupan lihat dalam Mun'im A. Sirry (ed.), Fiqih Lintas Agama (Jakarta: Paramadina, 2004), pp. 209-15. 
lain. Mereka mempunyai keprihatinan bersama mengenai kebutuhan air bersih, mengenai wabah demam berdarah, perumahan yang sehat, pembelajaran dan pendidikan yang sesuai, lapangan kerja, dan sebagainya. Mereka mengalami kondisi kehidupan bersama dan saling berbagi segala suka dan duka, keteguhan dan kekhawatiran, pengharapan dan kecemasan. Dalam dialog kehidupan itu, anggota-anggota komunitas hidup berdampingan dengan semangat kerukunan berkomunitas, bertetangga, dan berteman. Dari pengalaman hidup bersama itu munculah kepedulian bersama.

Pada dataran kedua, komunitas yang terdiri dari anggota-anggota berbagai agama itu mencoba mengartikan kenyataan hidup yang dialami dan membuat pertimbangan etis. Dengan kata lain, komunitas membuat analisis sosial dan merumuskan pilihan etis dalam konteksnya, menelaah faktor-faktor penyebab situasi tersebut dan berhubungan antar faktor. Analisis sosial tidaklah bebas nilai, karena itu, perlu disadari bersama nilai apa yang disepakati dan diperjuangkan dalam kelompok. Nilai-nilai itu misalnya kedamaian dan keadilan sosial, keadilan gender dan hak-hak asasi manusia, lingkungan hidup yang lestari dan berkelanjutan; juga misalnya kepedulian bersama akan nilai mendahulukan kebutuhan anggota yang paling miskin dan menderita dalam komunitas. Pada dataran ini, komunitas juga menentukan pilihan etis yang konkret sebagai bagian dari analisis sosial. Analisis sosial tersebut masih dapat diperdalam lagi dengan pertimbangan-pertimbangan yang didasarkan iman para anggota komunitas.

Dialog pada level pertama dan kedua ini jelas sangat tidak bisa dikesampingkan oleh berbagai umat beragama di Indonesia. Sebab dalam tataran sosial, baik dalam kehidupan biasa sehari-hari maupun dalam tugas mereka secara formal dalam pemerintahan misalnya, mereka semua berbaur satu sama lain. Problem-problem sosial yang mereka hadapi, seperti masalah pangan dan papan, masalah kesehatan dan pekerjaan, polusi dan termasuk pula pendidikan secara luas saling terkait di antara mereka.

Begitu pula, dalam penyelesaian problematika kehidupan sosial yang tengah menggelayuti mereka seyogyanya diselesaikan dengan cara yang bersifat objektif agar bisa diterima semua komunitas agama yang berbeda. Dengan kata lain, bila meminjam bahasa Cak Nur, solusi-solusi etis yang ditawarkan mesti dibungkus dengan bahasa yang bersifat inklusif, seperti keadilan, persamaan, kesejahteraan, kedamaian, dan lain-lain sehingga bisa menampung semua kepentingan umum. Karena itu, dialog dalam dimensi 
Mawa'izh

Jurnal Dakwah dan Pengembangan Sosial Kemanusiaan

Vol. 9, no. 2 (2018), pp. 154-177.

DOI: https://doi.org/10.32923/maw.v9i2.783

kehidupan sosial ini sangat signifikan dilakukan oleh beragam umat beragama di Indonesia untuk semakin mempererat kehidupan sosial di antara mereka.

Pada dataran ketiga, para anggota kelompok menggali tradisi iman masingmasing. Momen ini penting karena pilihan etis orang beriman juga dilandasi dan diperkuat oleh sumber iman masing-masing. Pada dataran ini, orang beragama dapat menegaskan keyakinannya mengenai apa yang menjadi kehendak Tuhan atau apa yang sejalan dengan Yang Ultim. Dapat terjadi bahwa kepedulian baru dalam konteks yang baru membawa tantangan untuk memaknai ulang tradisi tertentu, atau bahkan menemukan kembali tradisi yang sudah dilupakan. Pada dataran ini kepedulian manusiawi yang diikuti analisis sosial dan pertimbangan etis secara eksplisit disadari sebagai kepeduliaan iman, saya memahami kenyataan hidup dan panggilan etis ini dari mata iman saya.

Pada dataran keempat, dialog terjadi dengan berbagi pengalaman iman dalam komunitas lintas iman. Berpangkal pada tradisi iman dan agama masing-masing, para peserta berbagi pengalaman iman dan kekayaan spiritual. Dengan cara itu para peserta saling memperkaya satu sama lain. Orang beriman terlibat dengan imannya sendiri dalam keterbukaan terhadap tradisi-tradisi religius lain (commitment and openness). Mereka berbagi pengalaman doa, pengalaman kontemplasi, pengalaman mengenai cara-cara mencari, menemukan dan mengikuti Allah atau Misteri kehidupan. Melalui momen ini, umat beragama menghindari cara-cara manipulatif dan agresif dan sekaligus menimba kekayaan tradisi agama lain. ${ }^{17}$

Dalam level ketiga dan keempat ini, memang dibutuhkan kedewasaan sikap untuk mau mengerti dan memahami tradisi keimanan dari agama yang berbeda. Namun dalam konteks Indonesia, menurut pengamatan para ahli dan testimoni beberapa pemuka agama, sebenarnya sebagian besar umat beragama masih saling mau mengerti, mendengarkan, dan bersimpati terhadap tradisi keyakinan agama mereka masingmasing. Sikap simpati itu ditunjukkan dengan kesediaan mereka dalam menghadiri kegiatan masing-masing agama yang berbeda. Di sini, dialog antar umat beragama dalam tataran tradisi keyakinan mereka yang berbeda menemukan landasan normatifnya dalam perspektif Islam.

17 Bandingkan dengan Sirry, Fiqih Lintas, pp. 230-8. 
Pada dataran kelima, dialog terjadi dalam pergumulan teologis lintas iman dan agama. Teolog atau spesialisis berbagai bidang dapat berbagi pemahaman dalam level ilmiah. Mereka mengkomunikasikan pemahaman yang lebih mendalam mengenai warisan religius masing-masing seraya menghargai dan belajar dari pemahaman tradisitradisi lain. Pergumulan lintas iman dan agama diharapkan saling memperkaya dan juga dapat memunculkan pemaknaan ulang dan orientasi ulang tradisi dalam penghayatan iman aktual.

Dalam berbagi pergumulan teologis, proses historis setiap agama harus menjadi pertimbangan. Hal-hal yang masih perlu diteliti bahkan yang dicurigai perlu didiskusikan juga. Misalnya, suatu kelompok dapat mendiskusikan isu kristenisasi, islamisasi dan juga pandangan yang berbeda mengenai situasi sosial. Melalui pengalaman berbagi dan bersaksi, kelompok tersebut dapat lebih sadar bahwa interpretasi seseorang selalu terbatas; bahwa diperlukan proses dialog dan interpretasi ulang terus menerus.

Hubungan antaragama yang terbuka dan jujur memerlukan landasan teologis yang terbuka pula. Keterbukaan dalam praktik dan teologi akan menyuburkan satu sama lain. Dalam mengembangkan teologi yang terbuka, umat beragama tidak hanya perpikir secara tekstual melainkan juga secara kontekstual. Dalam komunitas beragama, hal itu berarti melakukan komunikasi intertekstual dan interkontekstual secara kritis. Dengan demikian, apa yang diterima sebagai pesan yang diwahyukan melalui teks, diungkapkan dan diwujudkan dalam dialog dengan kehidupan sehari-hari, begitu pula panggilan dan pesan yang diterima dalam hidup sehari-hari diteguhkan melalui dialog dengan teks. Dengan cara itu, teologi-teologi kontekstual dapat lebih mendekati pengalaman inti dari iman dan perwujudannya secara bertanggungjawab di sini, saat ini. ${ }^{18}$

Dataran keenam adalah dialog aksi. Dialog antaragama seharusnya mengkaji masalah-masalah sosial dan mengarah pada keterlibatan kemasyarakatan. Umat beragama tidak dapat menghindari kenyataan bahwa mereka merupakan bagian dari masyarakat dan politik. Harmoni antaragama tanpa kepedulian bersama untuk mengolah konteks sosial dan politik akan cenderung memelihara harmoni yang palsu dan tidak adil. Melalui dialog, aksi kelompok yang terdiri dari berbagai agama dapat memberdayakan rakyat dengan perspektif keadilan sosial, keadilan gender, hak asasi manusia, dan lingkungan hidup. Di tengah-tengah kenyataan kultural, politis, dan ekonomis yang 
ambivalen, respons kontekstual berarti menegaskan afirmasi atau konfrontasi untuk menuju transformasi kehidupan sosial dan politik. Kelompok umat lintas agama dengan demikian menjadi komunitas yang melayani kepentingan umum, menjadi komunitas dialogis dan transformatif. 19

Salah satu problema yang dihadapi sebagian umat beragama di Indonesia adalah adanya problem problem kristenisasi atau islamisasi. Sebenarnya problem tersebut walaupun tidak begitu dominan dalam kalangan umat beragama Katolik dan Islam, namun karena kedua agama tersebut mempunyai misi menyebarkan agama masingmasing kepada orang luar atau dakwah, maka tidak jarang terjadi saling kecurigaan di antara mereka. Sikap saling curiga ini terkadang mengakibatkan hubungan yang tidak harmonis antara sesama mereka.

Pada poin inilah, dialog level kelima dan keenam bisa memainkan peran signifikannya. Bagi umat Islam misalnya, tidak perlu mendakwahkan ajaran-ajaran agama mereka kepada umat beragama lain secara umum dan khususnya kepada umat Kristen dan Katolik. Begitu pula bagi umat Kristen dan Katolik, tidak perlu menyebarkan misi agama mereka kepada umat beragama lain secara luas dan khususnya terhadap kaum Muslim. Idealnya, dakwah atau misi mestinya berubah secara kualitatif dari paradigma lama dengan jalan mengajak atau membaptis orang-orang untuk memeluk Islam atau Katolik (Kristen) tetapi lebih membawa mereka kepada penyerahan diri kepada Tuhan. ${ }^{20}$

Demikian pula, tujuan utama sebuah dakwah atau misi keberagamaan setiap agama dalam era kontemporer bukan lagi mengajak orang luar masuk kedalam agama misionaris atau dai, melainkan memberi tuntunan bagi umat manusia secara luas, menawarkan makna hidup, menumbuhkan solidaritas kemanusiaan secara universal, memetakan problema-problema krusial yang tidak terlihat oleh masyarakat luas dan menawarkan solusi-solusi konkret bagi problema bersama, serta mendorong perubahan ekonomi, sosial, dan politik ke arah yang lebih baik.

Tentu saja kesadaran misi dan dakwah dalam tataran sosial-politik yang bersifat universal ini memang harus didialogkan antara para pemuka agama. Sebab merekalah yang lebih sering melakukan kegiatan misionaris atau dakwah dalam konteks kebangsaan. Sehingga clash atau benturan penyebaran agama antara umat Katolik dan Kristen dengan Islam di Indonesia tidak akan terjadi.

${ }^{19}$ Ibid., p. 238-54.

${ }^{20}$ Shihab, Islam Inklusif, p. 114. 
Sampailah pada dataran ke tujuh, yakni dialog intraagama. Setelah menjalani macam-macam dataran dialog antariman atau setelah mengalami dialog lintas iman dan lintas agama, setiap orang kembali pada iman pribadinya. Pada dataran ini selayaknya terjadi otokritik. Kritik terhadap penghayatan iman saya dapat berupa peneguhan, tetapi juga dapat berupa teguran. Hidup beriman dan beragama yang sudah diperkaya dapat mempengaruhi diri dan menjadikan lebih hidup lagi. Umat beragama menjadi orangorang beriman yang lebih baik secara personal dan komunal. Orang Islam menjadi Muslim yang lebih baik, orang Kristen menjadi Kristiani lebih baik, dan seterusnya. Sikap kritis terhadap diri sendiri dapat muncul sejak awal perjumpaan, tidak usah menunggu setelah semua dataran dialog pernah dilewati. Semakin mendalam perjumpaan lintas iman dan lintas agama, semakin mendalam juga perubahan dan perkembangan yang terjadi dalam menghidupi iman dan agamanya sendiri.

Level inilah yang oleh John S. Dunne dinamakan dengan istilah "passing over" atau melintas. Yaitu "melintas dari satu budaya kepada budaya yang lain, dari satu cara hidup kepada cara hidup yang lain, dari satu agama kepada agama yang lain". Tetapi itu saja belum cukup. Dunne menambahkan bahwa proses "melintas" itu harus diikuti oleh proses kembali (coming back), tetapi kembali dengan wawasan baru kepada budaya sendiri, cara hidup sendiri, agama sendiri. Dalam pandangan Dunne, proses melintas dan kembali itu harus dilakukan dengan cara yang kreatif dan simpatik. Sebab dengan cara seperti itu pengembaraan religius dan spiritual akan memperkaya pengalaman dan menambah wawasan baru kepada pelakunya. ${ }^{21}$

Tentu saja menurut Banawiratma, dialog juga dapat dilihat sebagai tujuan menengah atau sebagai tujuan instrumental. Dialog bukan merupakan tujuan akhir, melainkan sesuatu yang dijalankan untuk mencapai tujuan selanjutnya. Namun, tujuan hidup bersama tidaklah dapat dicapai dengan baik tanpa keterlibatan semua pihak. Dalam cakrawala holistik, partisipasi dan rasa bagi keseluruhan merupakan keutamaan. Dengan demikian, dialog merupakan gaya hidup orang beriman dan beragama, merupakan sesuatu yang perlu dan harus dijalankan kalau seseorang atau komunitas mau setia kepada panggilan manusiawi dan Ilahiah.

Berbagai dataran dialog dari bawah yang dijalani secara terbuka dan jujur akan memunculkan unsur-unsur yang penting untuk kehidupan bersama, yakni pertobatan

21 Komaruddin Hidayat \& Ahmad Gaus (eds.), Passing over Melintas Batas Agama (Jakarta: Paramadina, 2001). 
dan pengampunan. Bertobat berarti menyadari kekurangan, kesalahan dan dosa yang telah dilakukan sekaligus percaya akan belas kasih dan pengampunan Ilahi yang tanpa batas. Pertobatan merupakan pengharapan baru, sebab orang tidak terpenjara pada masa lalu, dan masa depan tetap terbuka. Kesediaan untuk mengampuni adalah tanda bahwa seseorang siap menerima pengampunan Ilahi yang tanpa batas. Sebaliknya, tidak bersedia mengampuni yang lain merupakan tanda bahwa seseorang tidak siap menerima belas kasih dan pengampunan Ilahi yang tanpa batas itu. ${ }^{22}$

Namun dalam pandangan Alwi Shihab, salah satu syarat keberhasilan suatu dialog adalah semangat saling menghormati dan bukan saling menaklukkan. Dalam bahasa Al-Qur'an, yang pertama adalah khilaf (ikhtilaf) (QS. 11: 118) yakni perbedaan pendapat yang dilakukan melalui jadal hasan (adu argumentasi yang baik); dan yang kedua adalah syiqaq (perbedaan yang mengarah kepada permusuhan). (QS. 4: 35). ${ }^{23}$

Dalam konteks Indonesia, dialog antarumat beragama baru akan membuahkan hasil optimal apabila pelaku dialog mampu untuk menanggalkan pandangan eksklusivisnya saat mencari titik-titik temu dengan mitra dialognya. Dengan menanggalkan pandangan eksklusivis tersebut tidak berarti bahwa pelaku dialog harus mengorbankan keyakinan akan kebenaran agamanya. Dia hanya dituntut untuk menghormati keyakinan mitra dialognya agar pencapaian titik-titik temu mudah terwujud. Di samping itu pelaku dialog diharapkan dapat memperkaya diri dari doktrin mitra dialognya dalam memantapkan keimanannya.

Seorang Muslim, misalnya, dapat memperdalam kecintaannya kepada Isa a.s saat ia berdialog dengan penganut kristen yang memandang Yesus sebagai titik sentral agamanya. Dari tradisi Kristen yang kaya dengan keistimewaan, superioritas, dan keunikan Isa a.s, seorang Muslim akan memantapkan kecintaanya kepada Isa a.s sesuai dengan tuntunan Islam. Demikianlah yang ditunjukan oleh beberapa sufi besar Islam dalam menempatkan Isa a.s sebagai teladan dalam menjelajahi kehidupan spiritual. Bagi sementara sufi, Isa a.s adalah model pendakian jiwa ke titik syuhud dan fana (penyaksian, anihilasi diri dalam sifat-sifat Allah). Belum lagi hasil dari riset beberapa penulis Kristen yang cukup berguna dalam "menggugat" umat Islam untuk memperdalam pemahaman agamanya.

\footnotetext{
22 Banawiratma et al., Dialog Antarumat, p. 14.

${ }^{23}$ Shihab, Islam Inklusif, p. 58.
} 
Demikian pula halnya dengan penganut Kristen. Mereka dapat memperoleh inspirasi dari Al-Qur'an untuk memantapkan keimanannya akan kebenaran ajaran Yesus, kebesaran dan keunikannya yang terekam dalam Al-Qur'an. Oleh sementara penganut Kristen, Al-Qur'an merupakan sumber inspirasi dalam memahami arti tauhid guna menyingkap misteri Trinitas, sekaligus menerima Nabi Muhammad Saw sebagai utusan Tuhan.

Pemuka-pemuka Kristen masa lalu seperti Theodore Abu Qurrah (abad ke-9), Yahya bin Adi (abad ke-10), dan Paul Antioch (abad ke-12), adalah contoh nyata figur yang banyak diilhami oleh Al-Quran dalam memantapkan pemahamannya terhadap ajaran Kristen. Qurrah menyatakan bahwa Muhammad Saw. jelas menempuh tapak para Nabi-nabi. Antioch memperjelas bahwa Muhammad Saw adalah utusan Tuhan kepada masyarakat non-Kristiani. Yahya bin Adi bahkan menulis yang berjudul Risalah Al-Tauhid yang menekankan arti keesaan Tuhan dalam Trinitas. Selain mereka, pemuka Kristen abad ke-12 juga tidak sedikit yang bersimpati kepada ajaran Islam berkat interaksinya dengan Al-Qur'an.

Lois Massignon, ahli dalam ilmu tasawuf Ibn Arabi, berhasil memuluskan jalan untuk mengubah pandangan Katolik terhadap Islam. Redaksi Vatikan II yang merupakan langkah revolusioner dalam pandangan Gereja terhadap Islam, banyak sumber dari refleksi Massignon. William Cantwell Smith, pernah berkata bahwa ajaran yang terkandung dalam Al-Qur'an-yang telah mempengaruhi ratusan juta manusia berupaya untuk menjadikannya sebagai pedoman kehidupan spiritual-dapat dipastikan bersumber dari Tuhan.

Kenneth Cragg, mengakui bahwa interaksi dengan Al-Qur'an mengantarnya untuk meyakini arti tauhid dalam Trinitas. Bagi Hans Kung, pemotretan diri Yesus dalam Al-Qur'an adalah yang terdekat kepada ajaran Kristen awal. Ia bahkan tak segan-segan berikrar bahwa "pada hakikatnya saya ini seorang Muslim yang mengikuti Yesus". Dengan nada serupa Bijlefeld secara terbuka menyatakan, "Banyak hal yang saya jumpai dalam AlQur'an, yang justru memantapkan keimanan saya sebagai pengikut Yesus yang sejati."

Terlepas dari tipologi perspektif teologis di atas dan tanpa berpretensi mengunggulkan satu pandangan atas lainnya, yang penting digarisbawahi adalah pemupukan semangat apresiatif terhadap pandangan mitra dialog baik intra atau antaragama. Praktik saling menuding kekurangan dan menonjolkan superioritas harus di kubur dalam-dalam. Kendati perbedaan pendapat (ikhtilaf) tak dapat dibendung, namun 
permusuhan yang membawa keretakan (syiqaq) harus dihindari. Bila semangat apresiatif terhadap doktrin mitra dialog dapat disosialisasikan di Indonesia, maka usaha untuk memantapkan kerukunan umat beragama tidak akan terlalu sulit dilaksanakan. Terpulang kepada komitmen komunitas agama semua sebagai umat beragama untuk menghayati dan mengaplikasikan semangat apresiasif ini.

Bagi umat Islam semangat ini secara eksplisit tertuang dalam Al-Qur'an (QS. 34: 24-26) sebagai pedoman berinteraksi dengan umat agama lain. Ayat-ayat ini menunjukkan bahwa segala perselisihan tidak harus diselesaikan kini di dunia, kesemuanya akan diselesaikan di hadapan Yang Maha Mengetahui dan Maha Adil, di Hari Kemudian. ${ }^{24}$

Di sinilah terlihat signifikansi berbagai konsep dialog di atas bagi pelbagai umat beragama di Indonesia. Sebagaimana kita ketahui, Cak Nur sangat menganjurkan sekali agar berbagai umat beragama di Indonesia senantiasa mengadakan dialog untuk menumbuhkan kearifan terhadap penganut agama yang berbeda satu sama lain. Tentu saja sebagaimana diuraikan di atas, aneka ragam level dialog tersebut tidak harus diaplikasikan secara keseluruhan sekali waktu, melainkan hanya diterapkan yang kiranya sesuai dengan konteks keberagamaan masyarakat Indonesia. Bercermin pada keberagamaan masyarakat kita, maka secara garis besar beberapa bentuk dialog tersebut memang dapat diimplementasikan setidaknya untuk mempererat kerukunan antar umat beragama dan menepiskan kecurigaan di antara mereka.

\section{Kerjasama Antar Umar Beragama}

Sejauh ini kita telah membahas asas-asas normativitas bagi kerukunan dan dialog antar umat beragama. Bahkan dialog tersebut, bukan hanya bergumul dengan wacanawacana secara konseptual, tapi juga harus menyentuh ranah praktis secara faktual. Namun menurut sebagian cendekiawan Muslim, harmonisasi antar umat beragama tidak boleh hanya berhenti pada level dialog, melainkan mesti dilanjutkan pada tataran praksis dalam bentuk kerjasama di antara mereka semua. Konstruksi kerukunan antar umat bergama yang hanya berhenti pada level dialog dan tidak melanjutkan pada kerjasama merupakan dialog setengah hati, bahkan terperangkap dalam verbalisme semata: dengan mengatakan sesuatu, maka merasa telah melakukannya. ${ }^{25}$

\footnotetext{
24 Ibid., pp. 58-60.

25 Madjid, et al., Fikih Lintas Agama (Jakarta: Paramadina, 2004), p. 238.
} 
Bila kita merujuk kepada Cak Nur, sebenarnya di sebagian besar tulisannya Cak Nur senantiasa menganjurkan kerjasama antar umat beragama. Analisis yang Cak Nur lakukan untuk selalu mencari titik-titik persamaan dan perjumpaan atau pijakan bersama antar semua umat beragama tidak hanya berhenti pada suatu lokus persamaan yang telah disepakati bersama. Lokus persamaan itu harus menjadi pijakan sekaligus pintu masuk untuk melakukan kerjasama dalam berbagai persoalan kemanusiaan-bagi seluruh umat beragama. Bahkan lebih jauh, bagi Cak Nur, kerjsama pada tataran sosial-kemanusiaan bukan hanya melibatkan semua umat beragama yang berbeda, tetapi juga mengundang semua umat manusia tanpa memandang latar belakang keagamaan mereka. Sebab kerjasama itu mesti membuahkan kebajikan dan manfaat kemanusiaan secara universal.

Namun menariknya, sebagaimana biasa sudah menjadi pandangan Cak Nur, kerjasama demi kebaikan universal umat manusia, bagi Cak Nur justru berangkat dari keyakinan agama (islam) itu sendiri: setiap orang (kaum muslim) memiliki tanggungjawab kepada Tuhan yang harus bermuara pada kebaikan umat manusia dan harus pula dipertanggungjawabkan kepada kemanusiaan. Jadi secara vertikal, tanggungjawab itu berpusat pada Tuhan; tapi secara horisontal karena setiap orang harus melakukan kebajikan kepada sesama umat manusia, maka semua kebajikan yang dikerjakannya harus dapat dipertanggungjawabkan di hadapan mahkamah kemanusiaan pula. "Disebabkan tanggungjawab kemanusiaan", tulis Cak Nur, "yang harus dilakukan oleh seorang penganut agama-dengan senantiasa berpijak pada prinsip persamaan, maka manusia diseru untuk senantiasa menggalang kerja sama atas dasar kebaikan dan tanggung jawab kepada Tuhan. Untuk itu, manusia didorong agar senantiasa mencari titik-titik persamaan sebanyak mungkin antara berbagai komunitasnya. Dan sepanjang mengenai Islam, titik persamaan yang penting ialah kesadaran ketuhanan dan tanggung jawab di hadapan Tuhan". 26

Bahkan lanjut Cak Nur, sesungguhnya persoalan umat manusia, termasuk persoalan yang dihadapi pada zaman modern ini, bisa direduksi menjadi semata-mata persoalan tanggungjawab manusia kepada Tuhan: sampai di mana mereka melaksanakan atau tidak melaksanakan tanggung jawab itu, dan sampai di mana pelaksanaan itu menyiapkan manusia menghadapi hari esok. ${ }^{27}$

26 Rachman, Ensiklopedi Nurcholish Madjid Vol. 2, p. 1484.

27 Ibid. 
Karena itu, kerjasama kemanusiaan pada gilirannya menghendaki kebebasan suatu kelompok dari klaim akan kebenaran mutlak. Setiap komunitas senantiasa mempunyai potensi untuk memiliki suatu jenis kebenaran, karena "tidak satu pun komunitas manusia lewat dalam sejarah, kecuali pasti pernah datang kepadanya pengajar kebenaran". Jadi, tidak ada hak istimewa yang eksklusif dari suatu komunitas untuk memiliki secara sendirian kebenaran itu. ${ }^{28}$

"Tuhan adalah tunggal, kebenaran pun tunggal, dan kemanusiaan juga tunggal adanya. Itu semua secara tak terhindarkan mengharuskan adanya kerja sama antar manusia "atas dasar kebaikan dan tanggung jawab kepada Tuhan, dan bukan atas dasar dosa dan rasa permusuhan". Dan itulah inti pandangan hidup yang terbuka bagi masa depan, salah satu yang diperlukan manusia dalam menghadapi tantangan abad modern", demikian tandas Cak Nur. ${ }^{29}$

Jadi berangkat dari premis Tuhan yang tunggal, kebenaran yang tunggal, dan kemanusiaan yang tunggal, meniscayakan kerjasama kemanusiaan secara universal di antara sesama umat manusia. Meminjam bahasa teolog Kristen kontemporer Paul F. Knitter, Cak Nur mengimbau kepada semua pemeluk agama-agama yang berbeda agar memiliki tanggungjawab global: bertanggungjawab terhadap dunia dan penghuninya yang berada di ambang kepunahan dengan bersama-sama mengentaskan kemiskinan dan kelaparan, menanggulangi kekerasan dan kezaliman, pelecehan terhadap wanita, perdagangan seks, pemerkosaan, dan lain-lain. Seluruh umat beragama mesti terpanggil dengan adanya pengalaman penderitaan bersama yang dialami oleh semua umat beragama dalam ranah sosial kemanusiaan. ${ }^{30}$

Akan tetapi, dalam konteks nasional-Indonesia, kita dapat melakukan kerjasama atau membentuk aliansi antar umat beragama dengan tujuan-tujuan yang relevan dengan problem aktual berikut:

\section{Aliansi Antar-Agama untuk Penangkalan Narkoba}

Sudah umum diketahui bahwa narkoba (narkotika dan obat-obatan terlarang) dewasa ini merupakan pembunuh yang paling keji, karena paling banyak menelan korban jiwa. Sebagian besar para korban itu adalah justru para remaja, yang merupakan generasi penerus bangsa. Peredaran narkoba kini tidak lagi hanya di lingkup terbatas sebagaimana

${ }^{28}$ Ibid.

${ }^{29}$ Ibid., pp. 1484-5.

${ }^{30}$ Lihat Paul F. Knitter, Pengantar Teologi Agama-Agama (Yaogyakarta: Kanisius, 2008), pp. 160-9. 
dulu, melainkan telah sangat ekspansif dan bahkan terang-terangan. Para pengedar itu mencari mangsanya bukan hanya di tempat-tempat "tradisional" seperti hiburan malam, tapi juga di lingkungan masyarakat sekitar kita, bahkan juga di sekolah-sekolah. Malah lebih parah lagi, sekolah-sekolah dasar pun kini tidak luput dari incaran para pengedar narkoba. Ini jelas ancaman untuk seluruh lapisan masyarakat, terutama kalangan umat beragama. Sebab, agama manapun pasti melarang umatnya mengkonsumsi narkoba.

\section{Aliansi Antar-Agama untuk Pemberantasan Pornografi}

Kontroversi mengenai pornografi sudah lama berlangsung di tanah air. Namun demikian, geliat pornografi belum pernah sebebas seperti sekarang ini, ketika euforia kebebasan dimaknai sebagai bebas tanpa batas. Media-media yang mengkhususkan diri menjajakan kemolekan tubuh perempuan kini bertebaran di mana-mana. Iklan-iklan yang menjajakan layanan seks tidak lagi menutup-nutupi diri alias blak-blakkan. Peredaran VCD porno kini juga bukan lagi barang mewah. Bagitu juga situs-situs internet yang mengkhususkan diri pada informasi dan pelayanan seks, kian banyak bermunculan. Semua bisa diakses oleh siapa saja.

Suara-suara yang memprotes pornografi tenggelam oleh hasrat publik untuk merayakan kebebasan. Yang terjadi malah sebaliknya, para penentang pornografi dituding sebagai kaum puritan, sok suci, munafik. Gelombang pornografi pun menggejala di mana. Berbagai kasus perkosaan, merebaknya kasus sodomi terhadap anak-anak, seks di luar nikah, dan lain-lain dianggap tidak ada hubungannya dengan fenomena pornografi yang diusung media massa. Lagi-lagi, dalam hal ini, agama tidak bisa berbuat banyak. Para mubalig hanya bisa menghimbau.

Pornografi telah menjadi problem sosial yang gawat, seperti halnya pengangguran, kemiskinan, dan lain-lain. Dalam jangka panjang akan ikut menciptakan budaya permisif, dan akhirnya merontokkan sendi-sendi moral masyarakat. Karena itu umat beragama (agama apa saja) harus benar-benar terlibat aktif membendung arus pornografi di tengah masyarakat kita. Seperti halnya pada program narkoba dan perjudian, problem pornografi pun harus menjadi agenda bersama umat beragama.

\section{Aliansi Antar-Agama untuk Penanganan Kriminalitas}

Problem sosial yang muncul akibat krisis ekonomi kian nampak telanjang di depan mata. Di simpang-simpang jalan para pengemis seperi berhamburan mengais rezeki dari belas kasihan orang. Anak-anak muda yang putus sekolah kian banyak jumlahnya. Mereka tertarik datang ke kota-kota besar; menjadai pengamen, atau pak 
ogah (polisi swasta di tikungan jalan), atau preman, atau bahkan gelandangan yang hidup di kolong-kolong jembatan layang. Mereka ini adalah ancaman bagi tatanan sosial, karena berbagai tindak kejahatan sangat akrab dengan keseharian mereka. Merka dibesarkan di lingkungan yang keras, dan mengidentifikasikan diri mereka melalui perspektif kekerasan; bahwa mereka adalah korban dari ketidakadilan sosial ekonomi yang hanya berpihak kepada segelintir orang. Melalui perspektif ini mereka membenarkan tindakan kekerasan untuk merampas hak milik orang lain. Dari situlah siklus kejahatan menjadi semacam lingkaran setan. Mereka terus diberantas oleh aparat dan para penegak hukum, tetapi kasus-kasus kejahatan sepertinya tidak pernah habis. Kenapa? Sebab yang diberantas adalah gejalanya, dan bukan sumbernya. Sumbernya jelas ketidakadilan sosial dan ketimpangan ekonomi.

Lantas, apa yang bisa dilakukan oleh agama untuk menangani masalah ini? Barangkali terlalu absurd membayangkan aktor-aktor agama bisa menyelesaikan masalah sosial seperti kejahatan. Tetapi jika soalnya adalah ketidakadilan dan ketimpangan ekonomi, maka agama-agama memiliki peranan paling tidak pada dua hal: pertama adalah dakwah ekonomi. Dalam hal ini perlu disosialisasikan pesan-pesan agama yang mendukung kedermawanan, solidaritas sosial, dan seruan untuk mendistribusikan kekayaan kepada orang-orang yang membutuhkan melalui jalan yang produktif. Misalnya, kerjasama untuk membuka usaha yang saling menguntungkan. Kini memang sudah mulai ada orang-orang kaya yang memberi modal kepada para penganggur dan korban PHK untuk memulai usaha seperti berdagang, bercocok tanam, dan lain-lain. Upaya semacam ini perlu terus digalakkan dengan semangat lintas agama. Sebab fenomena kemiskinan itu sendiri memang mengatasi batas-batas agama.

Selama ini kita melihat ada kesenjangan antara ajaran agama dengan realitas sosial. Agama mengajarkan untuk saling menolong dan menyantuni sesama. Tetapi umat beragama hidup sendiri-sendiri seperti terpisah dari orang lain. Ajaran berinfak hanya menjadi kata-kata hiasan di kitab suci. Fenomena kemiskinan tidak terlihat dari kerangka pemahaman agama semacam ini. Akibatnya, agama seperti terpisah dari problem sosial. Yang kedua adalah kerjasama agama untuk menangani hal-hal yang kongkrit akibat kemiskinan. Di sini yang dimaksud adalah penyantunan sosial, sebagaimana akan dipaparkan di bawah.

\section{Aliansi Antar-Agama untuk Penyantunan Sosial}


Saat ini banyak sekali kaum miskin baik di pedesaan maupun di perkotaan yang bukan saja tidak memiliki pekerjaan, tapi juga tidak memiliki tempat tinggal. Siang hari mereka hidup di jalanan, dan malam hari tidur di kolong-kolong jembatan atau emperan pertokoan. ${ }^{31}$ Kalangan umat beragama bisa berperan membentuk komite penyantunan sosial dengan cara mendirikan rumah singgah untuk gelandangan dan tunawisma, pantipanti sosial yang dikelola bersama, dan lain-lain. Gerakan ini bisa melibatkan kalangan swasta (individu ataupun instansi seperti perusahaan) yang peduli dengan masalah kemanusiaan. Sebagai aksi antar agama, gerakan ini akan memiliki legitimasi yang lebih kuat dan suara yang lebih vokal ketimbang aksi sendiri-sendiri.

Dalam hal ini, Father Bill's House di Boston (Amerika Serikat) barangkali bisa menjadi inspirasi dari gerakan semacam ini. Bill's House adalah rumah singgah bagi para gelandangan dan pengagguran. Mereka bisa memanfaatkan rumah ini untuk menetap selama mereka belum memperoleh pekerjaan. Selama tinggal di situ mereka mendapatkan jatah makan pagi, dan juga dicarikan pekerjaan. Jika di Amerika Serikat yang begitu maju saja problem sosial berupa pengangguran masih merebak, apalagi di negeri kita yang bukan saja masih terbelakang bahkan juga baru saja dihantam badai krisis ekonomi. Oleh karena itu, kepedulian semacam yang dilakukan oleh Father Bill dengan rumah singgahnya tentunya harus lebih banyak lagi di sini. ${ }^{32}$

\section{Aliansi Antar Agama untuk Penanggulangan Terorisme}

Terorisme dewasa ini telah menjadi fenomena global. Tindakan terorisme dapat dipahami sebagai suatu tindakan kejahatan yang dilakukan terhadap sasaran/obyek yang tidak terbatas, yaitu siapa saja walaupun tidak tersangkut ataupun tak tahu menahu mengenai persoalan yang dipermasalahkan oleh pelaku terorisme. Seperti kita ketahui bersama, aksi terorisme kini sangat marak dengan melakukan teror bom bunuh diri yang memakan korban sangat banyak, terutama justru orang-orang yang tidak berdosa dan bersalah. Karena itu harus ada kerjasama antar umat beragama untuk mengcounter aksi terorisme yang kian masif.

Tentu saja, meskipun aliansi antar umat beragama tidak bisa mengatasi terorisme pada level tindakan aksi mereka, namun para tokoh lintas agama dapat menetralisis pada level keyakinan, pemahaman, atau ideologi pada masyarakat luas. Sebab setiap aksi terorisme pasti digerakkan oleh keyakinan, paham, atau ideologi

\footnotetext{
31 Ibid., pp. 249-53.

32 Ibid., pp. 253-4.
} 
ekstrem yang diyakini oleh para pelaku tindakan terorisme. Disinilah pentingnya semua umat beragama, terutama para tokoh lintas agama melakukan rekonstruksi penafsiran ajaran agama yang bersifat konstruktif dan sosialisasi secara masif pula bahwa aksi terorisme merupakan tindakah kejahatan kemanusiaan yang tidak terampuni dosanya. Demikian pula, semua umat beragama harus bekerjasama guna mencari solusi terhadap berbagai tindakan terorisme secara moral-intelektual-spiritual, baik pada level nasional, regional, maupun global. ${ }^{33}$

\section{Aliansi Antar-Agama untuk Pemberantasan Korupsi}

Seperti terorisme, korupsi juga telah dianggap sebagai extra ordinary crime, kejahatan luar biasa. Semua umat beragama, terutama melalui para tokoh-tokohnya perlu melakukan tindakan bersama dalama rangka memberantas korupsi. Para ulama, pastur, pendeta, biksu, dan lainnya perlu memberikan pencerahan terhadap masyarakat Indonesia tentang keburukan korupsi. Sebagai misal, Din Syamsudin ketika menjadi Ketua Umum Pimpinan Pusat Muhammadiyah menegaskan bahwa koruspi adalah syrik modern karena tidak lagi meyakini Allah sebagai Tuhan, tetapi menjadikan uang sebagai sumber kekuatannya, the power of money. Senada dengan Din Syamsudin, KH. A. Hasyim Muzadi, Pengurus Besar Nahdlatul Ulama, dalam buku ini menggugat pemahaman atau anggapan bahwa korupsi merupakan suatu perbuatan tercela yang dapat diampuni. Cara pandang seperti itu, lanjutnya, harus diubah. Korupsi adalah perbuatan syirik. ${ }^{34}$

Sebagai contoh konkret, kita bisa melihat strategi pemberantasan korupsi yang dilakukan NU dan Muhammadiyah yaitu, pertama, organisasi keagamaan seperti NU dan Muhammadiyah mesti mampu membangun kemandirian dalam hal keuangan organisasi. Dengan kemandirian itu, organisasi tidak rentan terhadap suap, bantuan, atau hibah dari pejabat yang memiliki pamrih tertentu, dan juga terbebas dari uang hasil korupsi. Harapan yang paling mendasar adalah menjadikan organisasi keagamaan sebagai teladan dalam soal "kebersihan" dan independensi, sementara pada saat yang sama tetap dapat menyuarakan anti-korupsi secara vokal.

Kedua, NU dan Muhammadiyah perlu mengembangkan manajemen keuangan yang profesional sehingga dapat memisahkan secara tegas antara harta pribadi para tokohnya dan harta lembaga, institusi atau organisasi. Ketiga, mengupayakan bahasa dan semangat fiqih yang dapat ditransformasikan menjadi undang-undang sehingga 
berpengaruh di level yang lebih luas. Selain itu, Bahtsul Masail perlu diarahkan untuk mengubah kebijakan publik yang memihak kepentingan rakyat kecil dan menganjurkan pelaksanaan hajat rakyat banyak dengan lebih trasnparan, accountable, dan partisipatif. Oleh karena itu, tema yang diangkat juga mestinya berangkat dari problem-problem sosial yang benar-benar dihadapi rakyat yang terkait dengan penyelenggaraan kebijakan publik.

Keempat, meyakinkan dan memberi dorongan moral kepada jaringan politisi, khususnya berbasis ideologi NU atau Muhammadiyah di parlemen tanpa harys melihat partainya, untuk ikut serta membangun clean government. Kelima, mengampanyekan gerakan melawan korupsi secara terus-menerus agar tumbuh kesadaran anti-korupsi dalam beragama. Keenam, mengeluarkan fatwa pengharaman atas uang yang diterima dari hasil korupsi sebagaimana makan daging babi. Ketujuh, mengeluarkan fatwa bahwa menerima sumbangan, sekalipun untuk membangun masjid dan mengembangkan pesantren, dari uang hasil korupsi adalah haram. ${ }^{35}$ Demikianlah beberapa contoh gerakan aliansi antar umat beragama yang masih bisa dikembangkan lagi ke berbagai persoalan yang relevan.

\section{Penutup}

Jika kita menengok kembali noktah-noktah argumentasi yang diwacanakan oleh Cak Nur, kita melihat bagaimana Cak Nur memberikan pijakan dasar untuk membangun dialog dan kerjasama berlandaskan keprihatinan yang sama mengenai kemanusiaan. Bagi Cak Nur, dialog dan kerjasama itu meskipun harus memiliki sandaran (tanggungjawab) vertikal kepada Tuhan, tapi tetap harus bermuara kepada kebaikan dan manfaat kemanusiaan seluas-luasnya, melampaui batas-batas paham, keyakinan, agama, etnis, ras, budaya, dan bangsa. Setiap pemeluk agama perlu mempunyai semacam tanggungjawab global yakni memiliki solidaritas terhadap penderitaan kemanusiaan secara universal. Di sini muara keprihatinan, penghormatan, dan kepedulian kita adalah harkat-martabat manusia itu sendiri sebagai anugerah istimewah dari Tuhan.

Bahkan lebih jauh, kita harus menghormati dan menghargai martabat pemberian Tuhan kepada setiap manusia ini, termasuk musuh-musuh kita. Sebab, tujuan segenap hubungan manusia-entah itu hubungan keagamaan, sosial, politik, atau ekonomiadalah kerjasama dan saling menghormati. Tujuan ini hanya mungkin dicapai melalui 
Mawa'izh

Jurnal Dakwah dan Pengembangan Sosial Kemanusiaan

Vol. 9, no. 2 (2018), pp. 154-177.

DOI: https://doi.org/10.32923/maw.v9i2.783

dialog dan kerjasama yang bermakna, substantif, dan konstruktif di antara orang-orang beragama dalam tiap-tiap tradisi keagamaan. Dialog dan kerjasama juga tidak boleh sebatas wacana keagamaan, tetapi harus menyentuh hak-hak asasi manusia, isu-isu politis dan ekonomis, maupun isu keadilan sosial, dan hak semua orang di mana pun untuk hidup aman, sejahtera dan damai. ${ }^{36}$ 
Mawaizh

\section{DAFTAR PUSTAKA}

Abdullah, M. Amin, Studi Agama, Yogyakarta: Pustaka Pelajar, 1996.

Esposito, John. L. (ed), Ensiklopedi Oxford Dunia Islam Modern Jilid 4, trans. by Eva Y.N, et al., Bandung: Mizan, 2001.

----, Masa Depan Islam, Bandung: Mizan, 2010.

Hidayat, Komaruddin and Ahmad Gaus AF (eds.), Passing Over, Jakarta: Gramedia Pustaka Utama, 2001.

----, Kontroversi Khilafah, Islam, Negara, dan Pancasila, Bandung: Mizan, 2014.

J. B. Banawiratma, et.al, Dialog Antarumat Beragama, Bandung: Mizan, 2010.

Knitter, Paul F, Pengantar Teologi Agama-Agama, Yogyakarta: Kanisius, 2008.

Madjid, Nurcholish, Tradisi Islam. Jakarta: Paramadina, 1997.

----, Masyarakat Religius, Jakarta: Paramadina, 2000.

Madjid, Nurcholish, et al., Fikih Lintas Agama, Jakarta: Paramadina, 2004.

Misrawi, Zuhairi, Pandangan Muslim Moderat, Jakarta: Kompas, 2010.

Mubarak, Zaki, Genealogi Islam Radikal di Indonesia, Jakarta: LP3ES, 2008.

Rachman, Budhy Munawar (ed.), Ensiklopedi Nurcholish Madjid Vol. 2, Jakarta: Paramadian, 2006.

Shihab, Alwi, Membedah Islam Di Barat, Jakarta: Gramedia, 2011.

Sirry, Mun'im A. (ed.), Fiqih Lintas Agama, Jakarta: Paramadina, 2004.

Widjoyanto, Bambang (ed.), Koruptor Itu Kafir, Bandung: Mizan, 2010. 